\title{
Development of a Protocol and a Diagrammatic Scale for Quantification of Bacterial Leaf Streak Disease on Young Plants of Maize
}

\author{
Renata Rodrigues Robaina, ${ }^{1}$ Talita Vigo Longhi, ${ }^{1,2}$ Douglas Mariani Zeffa, ${ }^{3}$ Leandro Simões Azeredo Gonçalves, ${ }^{2,3}$ \\ and Rui Pereira Leite Jr., ${ }^{1,}$ \\ ${ }^{1}$ Instituto Agronômico do Paraná - IAPAR, Plant Protection Area, Londrina, PR, Brazil \\ ${ }^{2}$ Universidade Estadual de Londrina - UEL, Agronomy Department, Londrina, PR, Brazil \\ ${ }^{3}$ Universidade Estadual de Maringá - UEM, Agronomy Department, Maringá, PR, Brazil
}

\begin{abstract}
Bacterial leaf streak (BLS), caused Xanthomonas vasicola pv. vasculorum $(X v v)$, has become a major concern for maize production, mainly in the United States and South America. Therefore, this study aimed to establish a protocol for $X v v$ inoculation in young maize plants under controlled conditions and to develop and validate a diagrammatic scale for evaluation of maize hybrids in regard to BLS resistance. The study was carried out in three steps: the establishment of a protocol for inoculation of $X v v$ in young maize plants under controlled conditions; the development and validation of a diagrammatic scale for BLS severity evaluation; and the screening for

without injury inoculation method induced higher disease incidence and severity, as well as reproducibility of results under the experimental conditions established in this study. The proposed diagrammatic scale allowed evaluating BLS severity with up to $97.49 \%$ of the leaf area affected by the disease. Further, the use of the diagrammatic scale resulted in an increase of accuracy from 0.909 up to 0.992 . The reaction of 45 maize hybrids to BLS allowed establishing six major groups of susceptibility to the disease. The most resistant maize hybrids to BLS formed a group of 13 hybrids, with disease severity below $5 \%$.
\end{abstract} BLS resistance of 45 hybrids using the proposed protocol for bacterial inoculation and the diagrammatic scale developed in this study. Besides reproducing a more natural $X v v$ infection, the bacterial suspension spraying
Keywords: Zea mays, bacterial disease, inoculation method, Xanthomonas vasicola pv. vasculorum
The genus Xanthomonas includes gram-negative plant pathogenic bacteria that cause diseases on a wide range of mono- and dicotyledonous plants of economic importance (Jacques et al. 2016). Among them, $X$. vasicola pv. vasculorum $(X v v)$, the causal agent of bacterial leaf streak (BLS) of maize, has raised major concerns recently for maize production in United States and some South American countries (Broders 2017; Leite et al. 2018a; Plazas et al. 2018).

BLS has been reported occurring naturally on maize in South Africa since the 1940s (Karamura et al. 2015). Furthermore, the disease has recently also been detected in maize-producing regions of the U.S. Midwest, Argentina, and Brazil, reaching epidemic levels in some areas (Broders 2017; Lang et al. 2017; Leite et al. 2018a; Plazas et al. 2018). In Brazil, the first symptoms of the disease were observed in commercial fields in the western region of the state of Paraná in 2016. A rapid spread of the disease occurred to the western, midwestern, and northern regions of the state of Paraná in the 2018 growing season (Leite et al. 2018b).

Typical BLS symptoms on leaves are initially small translucent spots ( 2 to $3 \mathrm{~mm}$ ) that evolve to elongate and narrow lesions between veins, surrounded by a yellow halo (Lang et al. 2017). The edges of the lesions are undulated, which is an important characteristic to differentiate BLS from other maize diseases (Leite et al. 2018b). The lesions can cover a large part of the leaf area and may also develop in the ear bracts. The bacterium can survive on infected crop residues and also on alternative hosts (Broders 2017). Xvv can be disseminated by wind, rainwater, and possibly contaminated seeds (Arias et al. 2018).

Little information regarding BLS prevention and control is available so far (Broders 2017). Thus, management recommendations have been based on general measures for bacterial disease control.

${ }^{\dagger}$ Corresponding author: R. P. Leite Jr.; ruileite@iapar.br

The author(s) declare no conflict of interest.

Accepted for publication 5 May 2020.

(c) 2020 The American Phytopathological Society
Among them, genetic resistance is an important control measure. Identification of sources of resistance for inclusion in breeding programs requires accurate and reliable methods of bacterial inoculation and disease quantification.

Inoculation methods are essentials for studies of host-pathogen interactions, including for disease resistance in breeding programs. In addition, it is important that the method can provide a closer reproduction of the infection process that occurs under natural conditions. Bacterial suspension sprays on injured or uninjured plant parts and syringe infiltration are among the most used methods for inoculation of plant pathogenic bacteria. For instance, Xanthomonas euvesicatoria, a nonvascular bacterium that enters leaves through stomata and colonizes the intercellular spaces of the mesophyll parenchyma, is usually inoculated in tomato plants by leaf infiltration (Kim et al. 2008). The immersion of shoots into a bacterium suspension has been considered an efficient and reliable technique to screen for resistance against bacterial spot of stone fruits caused by Xanthomonas arboricola pv. pruni (Socquet-Juglard et al. 2012). On the other hand, Xanthomonas oryzae pv. oryzae, which causes a vascular disease on rice starting with infection on leaves through wounds and hydathodes, is commonly inoculated by leaf clipping using scissors previously immersed in a bacterial suspension (Kauffman et al. 1973). In cassava, several methods of inoculation of Xanthomonas phaseoli pv. manihotis in the plant have been evaluated in material grown from stem cuttings (Jorge and Verdier 2002). These methods include clipping leaves with contaminated scissors (Lozano and Laberry 1982), spraying foliage, depositing bacterial suspensions on mechanically generated leaf holes, and stem puncturing (Jorge and Verdier 2002; Restrepo et al. 2000). However, limited studies have been reported on inoculation methods for $X v v$ on maize (Coutingo and Wallis 1991).

Among the methods of disease quantification, severity is a commonly used parameter, although it is subjective. To reduce subjectivity and to increase accuracy and precision of the evaluation, diagrammatic scales and trained evaluators are of the utmost importance (Del Ponte et al. 2017). Furthermore, diagrammatic scales that include sets of images of plants or plant parts with different levels of disease severity can provide reproducibility, exactness, and precision of results (Bock et al. 2015). 
Most diagrammatic scales have been developed and validated for maize leaf diseases under field conditions (Malagi et al. 2011; Sachs et al. 2011; Vieira et al. 2014). However, the risk of occurrence of disease symptoms caused by other pathogens increases under field conditions, which may interfere with the identification and quantification of the target disease. Further, early disease evaluations under greenhouse conditions using appropriate protocols may minimize biotic and abiotic factors and can be an important strategy in the study of different aspects of plant diseases, for example, in breeding programs to increase the accuracy and precision in the screening for disease resistance. In addition, early evaluations of maize progenies make it possible to reduce the time and costs in these screenings for disease resistance, allowing more agility and safety in the breeding programs.

The present study aimed to establish a protocol for inoculation of $X v v$ in young maize plants under controlled conditions and to develop and validate a diagrammatic scale to evaluate maize lines and hybrids. Further, the proposed diagrammatic scale was used to evaluate 45 commercial maize hybrids regarding the reaction to BLS.

\section{Materials and Methods}

The study was carried out in three stages. Initially, a protocol was established for the inoculation of the bacterium $X v v$ in young maize plants under controlled conditions. Then, a diagrammatic scale for evaluation of BLS severity on young maize plants was developed and validated, and, finally, the reaction of 45 commercial maize hybrids to the disease was evaluated using the proposed inoculation protocol and diagrammatic scale. In all experiments, we used the RL1 strain of $X v v$ (Leite et al. 2018a) from the bacterial culture collection of the Bacteriology Laboratory of the Instituto Agronômico do Paraná (IAPAR), Londrina, PR, Brazil. Further, all the studies were carried out in a semiclimatized greenhouse at the Londrina Experimental Station of IAPAR, Londrina, PR, Brazil.

Establishment of a protocol for inoculation of $X v v$ in young maize plants. The hybrid IPR 164 was used in the tests to establish the protocol for $X v v$ inoculation on young plants of maize under controlled conditions. The maize hybrid was sown in 5-liter plastic pots containing a soil/sand/organic matter mixture (3:1:1). Twelve days after sowing, the plants at the V3 stage were artificially inoculated with the bacterial suspension at a concentration of $1 \times 10^{8} \mathrm{CFU} / \mathrm{ml}$ of the RL1 strain of $X v v$. The bacterial suspension was prepared without addition of any surfactant to reproduce as closely as possible the conditions of natural infection. The following inoculation methods were tested: (i) syringe injection, in which approximately $2 \mathrm{ml}$ of the bacterial suspension was injected in the whorl of the plant with a hypodermic syringe; (ii) deposition of the bacterial suspension in the leaf whorl, in which approximately $2 \mathrm{ml}$ of the bacterial suspension was placed in the central whorl of the plant with a pipette; (iii) spraying on injured leaves, in which leaves were injured with multipoint needles and approximately $10 \mathrm{ml}$ of the bacterial suspension was sprayed on the leaves; and (iv) spraying without injury, in which approximately $10 \mathrm{ml}$ of the bacterial suspension was sprayed on the leaves. All plants were maintained in a moist chamber for $24 \mathrm{~h}$ before and $24 \mathrm{~h}$ after inoculation. Disease incidence and severity were evaluated at 9 and 15 days after inoculation.

The statistical design was completely randomized, in a factorial scheme, with three plants per plot and four replications. The data analysis for incidence and severity of the disease was performed using nonparametric statistics. The ANOVA-type statistic (ATS), which has an approximate $\mathrm{F}$ distribution under the null hypothesis based on asymptotic theory, was applied to the data (Brunner et al. 1997; Brunner and Puri 2001). Comparison of the inoculation methods was performed by Bonferroni test $(P<0.05)$ and the analysis was performed using the $\mathrm{R}$ software packages nparLD (Noguchi et al. 2012) and agricolae (Mendiburu and Simon 2015).

Development and validation of a diagrammatic scale for assessment of BLS severity on young maize plants. For the development of the diagrammatic scale, maize hybrids with different levels of resistance to BLS were sown in 5-liter plastic pots containing a soil/sand/organic matter mixture (3:1:1). Twelve days after sowing, the plants at the V3 stage were inoculated using the spraying without injury method as described previously. Fifteen days after inoculation, leaves of the V3 and V4 stages with different levels of severity of BLS were collected to form a set of leaves to establish the diagrammatic scale.

A total of 300 maize leaves with different levels of BLS severity were used to establish the diagrammatic scale. The leaves were scanned at $300 \mathrm{dpi}$, and the images were used to determine the real severity level using the software Asses 2.0 (American Phytopathological Society, St. Paul, MN). Nine images were used to represent the minimum, intermediate, and maximum levels of BLS severity. The diagrammatic scale was elaborated using the software Adobe Photoshop.

The proposed diagrammatic scale was validated by five evaluators with previous experience in plant disease assessment (E1 to E5) and by five unexperienced evaluators (E6 to E10). A total of 50 images of maize leaves with different BLS severity levels were organized in a Microsoft PowerPoint presentation with one slide per image. The first set of evaluations was performed without using the diagrammatic scale, and then the same evaluators received the same rearranged images for assessment based on the proposed diagrammatic scale.

The diagrammatic scale was validated based on precision, accuracy, and reproducibility of the evaluations by simple linear regression analysis (Campbell and Madden 1990; Kranz 1988; Nutter and Schultz 1995). The model $Y_{i}=\beta_{O}+\beta_{I} X_{i}+\varepsilon_{i}$ was used, where $Y_{i}$ is the $i^{\text {th }}$ estimated severity; $\beta_{O}$ and $\beta_{1}$ are the linear and angular regression coefficients, respectively; $X_{i}$ is the real severity; and $\varepsilon_{i}$ the error associated with $Y_{i}$.

The precision of each evaluation estimate was measured by the regression determination coefficient $\left(R^{2}\right)$, the absolute error variance between the real and estimated severities, and the mean square error (MSE). Regarding the accuracy of the evaluations, the estimates $\beta_{O}$ and $\beta_{1}$ were tested by the $t$ test. The null hypothesis was that $\beta_{0}=0$ and $\beta_{1}=1$, with $\alpha=0.05$, and their acceptance indicates accuracy in the real severity assessment. The reproducibility of the estimates was assessed by comparing the standard deviation among the evaluators by the criteria $R^{2}, \beta_{0}, \beta_{1}$, and MSE.

Evaluation of maize hybrids for resistance to BLS under greenhouse conditions. The reaction of 45 maize hybrids to BLS was assessed based on inoculation of young plants and evaluation using the proposed diagrammatic severity scale. The hybrids were sown in 5-liter plastic pots containing a soil/sand/organic matter mixture (3:1:1). Twelve days after sowing, the plants at the V3 stage were inoculated using the spraying without injury method as described previously. Disease severity was evaluated 15 days after inoculation (DAI) using the proposed diagrammatic scale. The statistical design was completely randomized, with three plants per plot and four replications.

Data were subjected to the assumptions of variance analysis, including independence, normal distribution, and constant variance (Rawlings et al. 1998). Because the assumptions were met, the data were subjected to analysis of variance and subsequently to the cluster analysis of Scott and Knott (1974). The statistical analyses were carried out using the $\mathrm{R}$ program (http://www.r-project.org) with the $\mathrm{R}$ package easyanova (Arnhold 2013).

\section{Results}

Establishment of a protocol for inoculation of $X v v$ in young plants of maize. The symptoms of BLS on leaves of the artificially inoculated young maize plants using different inoculation methods were similar to those observed in the field under natural conditions of infection by the $X v v$ bacterium. The first symptoms were observed 9 DAI, as small water-soaked translucent lesions when observed against the light. These symptoms evolved to elongated and narrow lesions between veins surrounded by a yellow halo. The spraying without injury inoculation method provided the widest range of leaf stage infections, with BLS lesions on leaves from the V1 through the V8 vegetative leaf stages (Table 1). In contrast, the leaf whorl deposition method provided the narrowest range of leaf stage infections, 
with BLS lesions present only on the V5 and V6 vegetative leaf stages (Table 1).

ATS analysis showed a significant effect on BLS incidence and severity in maize leaves in regard to the inoculation method, maize leaf stage, and inoculation method $\times$ maize leaf stage interaction (Table 2). As mentioned, the method of bacterial suspension deposition in the leaf whorl resulted in the lowest BLS incidence as well as disease severity compared with the other inoculation methods (Table 1). Further, symptoms were only observed on leaves of the stages V6 at 9 DAI and V5 and V6 at 15 DAI, with less than $8.25 \%$ diseased leaves in all these cases (Table 1 ). The severity values were less than $0.50 \%$ for the stage V5 at $9 \mathrm{DAI}$ and below $1.50 \%$ for the leaf stages V5 and V6 at 15 DAI (Table 1). In contrast, the spraying without injury method provided symptoms of BLS on leaves of the stages V3 through V8, as early as 9 DAI (Table 1). Further, disease incidence reach values of $100 \%$ of symptomatic leaves in some leaf stages (Table 1). This method of inoculation provided BLS severity higher than $30 \%$ in the V2, V3, and V4 leaf stages at 15 DAI (Table 1).

The spraying with injury method provided the highest levels of BLS incidence and severity, but the disease was restricted to the V2 and V3 leaf stages (Table 1). In contrast, the syringe injection method also resulted in high levels of BLS incidence and severity on leaves of most of the different vegetative stages (Table 1). The plants inoculated with the syringe injection method had the highest incidence of the disease on V5 leaves, with levels above $90 \%$ incidence at 9 and $15 \mathrm{DAI}$, with severity of 31.92 and $34.75 \%$, respectively (Table 1). On the other hand, leaves of the stages V4 and V6 had disease incidences below 60 and $75 \%$ at 9 and 15 DAI, respectively (Table 1). Further, the disease severity in these leaves was much lower compared with the leaf stage V5 (Table 1). For the spraying without injury method, the highest incidence at 9 DAI was observed on V3 and V4 leaves, with $77 \%$ symptomatic leaves with severity of 22.50 and $27.08 \%$, respectively (Table 1). At 15 DAI, incidence and severity were higher on leaves of the V2, V3, and V4 leaf stages, with values reaching 100 and $33.30 \%$, respectively (Table 1). Besides reproducing a more natural $X v v$ infection under field conditions, the spraying inoculation without injury method induced higher disease incidence, severity, and reproducibility of results under the experimental conditions. Therefore, this method of inoculation was chosen to carry out the other steps of this study.
Development and validation of a diagrammatic scale for assessment of BLS of maize. The proposed diagrammatic scale allows evaluating BLS severity in young plants of maize with up to $97.49 \%$ of the leaf area affected by the disease (Fig. 1). Further, the use of the diagrammatic scale resulted in a general increase of accuracy, from 0.909 up to 0.992 (i.e., a $9.13 \%$ increase in the precision of the actual severity estimates) and a consequent decrease of the error, from 6.87 down to 1.87 (Table 3). In general, the accuracy in the disease evaluation by the experienced evaluators was slightly more precise than that of the unexperienced ones without using the diagrammatic scale (Table 3). Whereas the experienced evaluators had a precision of $92.70 \%$ in disease severity accuracy, the unexperienced ones had a precision of $89.20 \%$ (Table 3). However, both groups of evaluators had almost the same result in disease evaluation when using the

Table 2. Nonparametric ANOVA-type statistics (ATS) for the effects of inoculation method (IM), maize vegetative leaf stage (MLS), and the interaction on incidence and severity of the bacterial leaf streak, caused by Xanthomonas vasicola pv. vasculorum, on young plants of maize hybrid IPR 164

\begin{tabular}{lccc}
\hline Effect & ATS & DF $^{\mathbf{y}}$ & $\boldsymbol{P}$ value \\
\hline Incidence & & & \\
9 DAI & & & \\
IM & 27.13 & 1.79 & $<0.0001$ \\
MLS & 12.82 & 5.38 & $<0.0001$ \\
IM $\times$ MLS & 10.54 & 7.21 & $<0.0001$ \\
15 DAI & & & \\
IM & 41.69 & 1.72 & $<0.0001$ \\
MLS & 27.78 & 6.33 & $<0.0001$ \\
IM $\times$ MLS & 7.71 & 7.34 & $<0.0001$ \\
Severity & & & \\
9 DAI & & & \\
IM & 26.59 & 2.08 & $<0.0001$ \\
MLS & 8.38 & 5.13 & $<0.0001$ \\
IM $\times$ MLS & 11.72 & 7.67 & $<0.0001$ \\
15 DAI & & & \\
IM & 48.51 & 2.19 & $<0.0001$ \\
MLS & 11.15 & 5.92 & $<0.0001$ \\
IM $\times$ MLS & 10.20 & 7.73 & $<0.0001$ \\
\hline
\end{tabular}

${ }^{y}$ Degrees of freedom.

${ }^{\mathrm{z}} \mathrm{DAI}=$ days after inoculation

Table 1. Incidence and severity of bacterial leaf streak, caused by Xanthomonas vasicola pv. vasculorum, on different leaf stages of maize plants of hybrid IPR 164 inoculated by four different methods

\begin{tabular}{|c|c|c|c|c|c|c|c|c|}
\hline Inoculation method & $\mathbf{V} 1^{x}$ & $\mathbf{V} 2$ & $\mathbf{V 3}$ & V4 & V5 & V6 & V7 & V8 \\
\hline \multicolumn{9}{|l|}{ Incidence $(\%)$} \\
\hline \multicolumn{9}{|l|}{$9 \mathrm{DAII}^{\mathrm{y}}$} \\
\hline Syringe infiltration & $0.00 \mathrm{a}^{\mathrm{z}}$ & $8.25 \mathrm{bc}$ & $8.25 \mathrm{~b}$ & $50.00 \mathrm{a}$ & $91.75 \mathrm{a}$ & $57.00 \mathrm{a}$ & $16.75 \mathrm{a}$ & $8.25 \mathrm{a}$ \\
\hline Spraying without injury & $8.25 \mathrm{a}$ & $50.25 \mathrm{ab}$ & $77.00 \mathrm{a}$ & $77.00 \mathrm{a}$ & $37.50 \mathrm{~b}$ & $0.00 \mathrm{~b}$ & $25.00 \mathrm{a}$ & $8.25 \mathrm{a}$ \\
\hline Spraying with injury & $0.00 \mathrm{a}$ & $100.00 \mathrm{a}$ & $100.00 \mathrm{a}$ & $0.00 \mathrm{~b}$ & $0.00 \mathrm{c}$ & $0.00 \mathrm{~b}$ & $0.00 \mathrm{~b}$ & $0.00 \mathrm{a}$ \\
\hline Leaf whorl deposition & $0.00 \mathrm{a}$ & $0.00 \mathrm{c}$ & $0.00 \mathrm{~b}$ & $0.00 \mathrm{~b}$ & $0.00 \mathrm{c}$ & $8.25 \mathrm{~b}$ & $0.00 \mathrm{~b}$ & $0.00 \mathrm{a}$ \\
\hline \multicolumn{9}{|l|}{$15 \mathrm{DAI}$} \\
\hline Syringe infiltration & $0.00 \mathrm{a}$ & $33.25 \mathrm{bc}$ & $41.75 \mathrm{~b}$ & $73.00 \mathrm{a}$ & $100.00 \mathrm{a}$ & $63.00 \mathrm{a}$ & $41.50 \mathrm{a}$ & $8.25 \mathrm{a}$ \\
\hline Spraying without injury & $25.00 \mathrm{a}$ & $77.00 \mathrm{ab}$ & $100.00 \mathrm{a}$ & $100.00 \mathrm{a}$ & $94.00 \mathrm{a}$ & $8.25 \mathrm{~b}$ & $33.50 \mathrm{a}$ & $8.25 \mathrm{a}$ \\
\hline Spraying with injury & $0.00 \mathrm{a}$ & $100.00 \mathrm{a}$ & $100.00 \mathrm{a}$ & $0.00 \mathrm{~b}$ & $0.00 \mathrm{~b}$ & $0.00 \mathrm{~b}$ & $0.00 \mathrm{~b}$ & $0.00 \mathrm{a}$ \\
\hline Leaf whorl deposition & $0.00 \mathrm{a}$ & $0.00 \mathrm{c}$ & $0.00 \mathrm{c}$ & $0.00 \mathrm{~b}$ & $8.25 \mathrm{~b}$ & $8.25 \mathrm{~b}$ & $0.00 \mathrm{~b}$ & $0.00 \mathrm{a}$ \\
\hline \multicolumn{9}{|l|}{ Severity $(\%)$} \\
\hline \multicolumn{9}{|l|}{9 DAI } \\
\hline Syringe infiltration & $0.00 \mathrm{a}$ & $0.42 \mathrm{~b}$ & $0.42 \mathrm{~b}$ & $3.67 \mathrm{~b}$ & $31.92 \mathrm{a}$ & $13.33 \mathrm{a}$ & $4.58 \mathrm{a}$ & $2.08 \mathrm{a}$ \\
\hline Spraying without injury & $4.17 \mathrm{a}$ & $20.83 \mathrm{a}$ & $22.50 \mathrm{a}$ & $27.08 \mathrm{a}$ & $2.75 \mathrm{~b}$ & $0.00 \mathrm{~b}$ & $0.00 \mathrm{~b}$ & $0.00 \mathrm{a}$ \\
\hline Spraying with injury & $0.00 \mathrm{a}$ & $25.83 \mathrm{a}$ & $23.17 \mathrm{a}$ & $0.00 \mathrm{~b}$ & $0.00 \mathrm{~b}$ & $0.00 \mathrm{~b}$ & $0.00 \mathrm{~b}$ & $0.00 \mathrm{a}$ \\
\hline Leaf whorl deposition & $0.00 \mathrm{a}$ & $0.00 \mathrm{~b}$ & $0.00 \mathrm{~b}$ & $0.00 \mathrm{~b}$ & $0.00 \mathrm{~b}$ & $0.42 \mathrm{~b}$ & $0.00 \mathrm{~b}$ & $0.00 \mathrm{a}$ \\
\hline \multicolumn{9}{|l|}{$15 \mathrm{DAI}$} \\
\hline Syringe infiltration & $0.00 \mathrm{~b}$ & $1.25 \mathrm{~b}$ & $2.75 \mathrm{~b}$ & $10.08 \mathrm{a}$ & $34.75 \mathrm{a}$ & $17.00 \mathrm{a}$ & $6.83 \mathrm{a}$ & $2.08 \mathrm{a}$ \\
\hline Spraying without injury & $9.58 \mathrm{a}$ & $31.75 \mathrm{a}$ & $30.33 \mathrm{a}$ & $33.30 \mathrm{a}$ & $12.50 \mathrm{a}$ & $2.91 \mathrm{~b}$ & $2.58 \mathrm{a}$ & $0.83 \mathrm{a}$ \\
\hline Spraying with injury & $0.00 \mathrm{~b}$ & $33.50 \mathrm{a}$ & $38.00 \mathrm{a}$ & $0.00 \mathrm{~b}$ & $0.00 \mathrm{~b}$ & $0.00 \mathrm{~b}$ & $0.00 \mathrm{~b}$ & $0.00 \mathrm{a}$ \\
\hline Leaf whorl deposition & $0.00 \mathrm{~b}$ & $0.00 \mathrm{~b}$ & $0.00 \mathrm{~b}$ & $0.00 \mathrm{~b}$ & $1.25 \mathrm{~b}$ & $0.67 \mathrm{~b}$ & $0.00 \mathrm{~b}$ & $0.00 \mathrm{a}$ \\
\hline
\end{tabular}

$\mathrm{x}$ Vegetative leaf stage.

${ }^{\mathrm{y}} \mathrm{DAI}=$ days after inoculation.

${ }^{\mathrm{z}}$ Values followed by the same letter in the column for each DAI do not differ according to the Bonferroni test $(P<0.05)$. 
diagrammatic scale for BLS assessment, with a slightly higher $R^{2}$ for the unexperienced ones (Table 3 ).

The absolute error estimates of the severity assessments without using the diagrammatic scale ranged from -32.18 up to $27.94 \%$ (Fig. 2). On the other hand, the use of the scale provided a reduction in these absolute error estimates that ranged from -11.25 to up to $8.99 \%$ (Fig. 2). In general, the absolute errors of the evaluators using the scale were concentrated mostly in the near zero range, compared with those of the same evaluators in assessments without using the diagrammatic scale (Fig. 2).

In regard to the accuracy of the evaluations, the $\beta_{O}$ and $\beta_{I}$ estimates of all evaluators using the diagrammatic scale were nonsignificative by the $t$ test $(P>0.05)$, indicating a high accuracy of the BLS severity estimates (Table 3 ). However, $\beta_{0}$ for evaluator E9 was significative $(P<0.05)$ in the severity evaluations without the scale (Table 3). In general, the reproducibility of the severity assessments of the evaluators using the diagrammatic scale was higher than that for the evaluators not using scale, because the standard deviation values for $R^{2}, \beta_{O}, \beta_{l}$, and MSE of the evaluations were the lowest (Table 3 ).

Evaluation of maize hybrids for resistance to BLS under greenhouse conditions. The protocol of inoculation spraying without injury was used for the evaluation of the reaction of 45 maize hybrids to BLS. Further, the leaves of the vegetative stages V3, V4, and V5 were evaluated in regard to disease severity by using the proposed diagrammatic scale to evaluate BLS in the young maize plants.

The analysis of variance showed a significative effect $(P<0.01)$ for source of variation due to genotypes, indicating a wide variability in response to BLS susceptibility. The coefficient of variation was $18.2 \%$, and the severity values ranged from 0.3 for the genotype 1 up to $40.0 \%$ for the maize hybrid 45 (Fig. 3).

The reaction of the maize hybrids to BLS allowed the establishment of six major groups based on cluster analysis of Scott and Knott (1974) (Fig. 3). The most resistant maize hybrids to BLS formed a group of 13 hybrids, with disease severity below 5\% (Fig. 3). In contrast, the most susceptible group comprised three maize hybrids, with BLS severity above $35 \%$ (Fig. 3). The rest of the hybrids formed four major groups, with disease severity ranging from 5 up to $35 \%$ (Fig. 3).

\section{Discussion}

The bacterium $X v v$ causes BLS, an emerging maize disease that has become a major concern for growers, particularly in the United States, Argentina, and Brazil (Korus et al. 2017; Leite et al. 2018b; Plazas et al. 2018). Reliable protocols to reproduce the disease under controlled conditions are essential to allow different kinds of studies on BLS, such as screening for disease resistance in early stages of the maize plants.

In our studies, the highest BLS incidence and severity levels were obtained with the syringe injection and spraying without injury inoculation methods. These two methods have also been used for inoculation of other Xanthomonas spp. (Jorge and Verdier 2002; Kim et al. 2008; Restrepo et al. 2000). Plant pathogenic bacteria usually infect plants through wounds and natural plant openings, such as

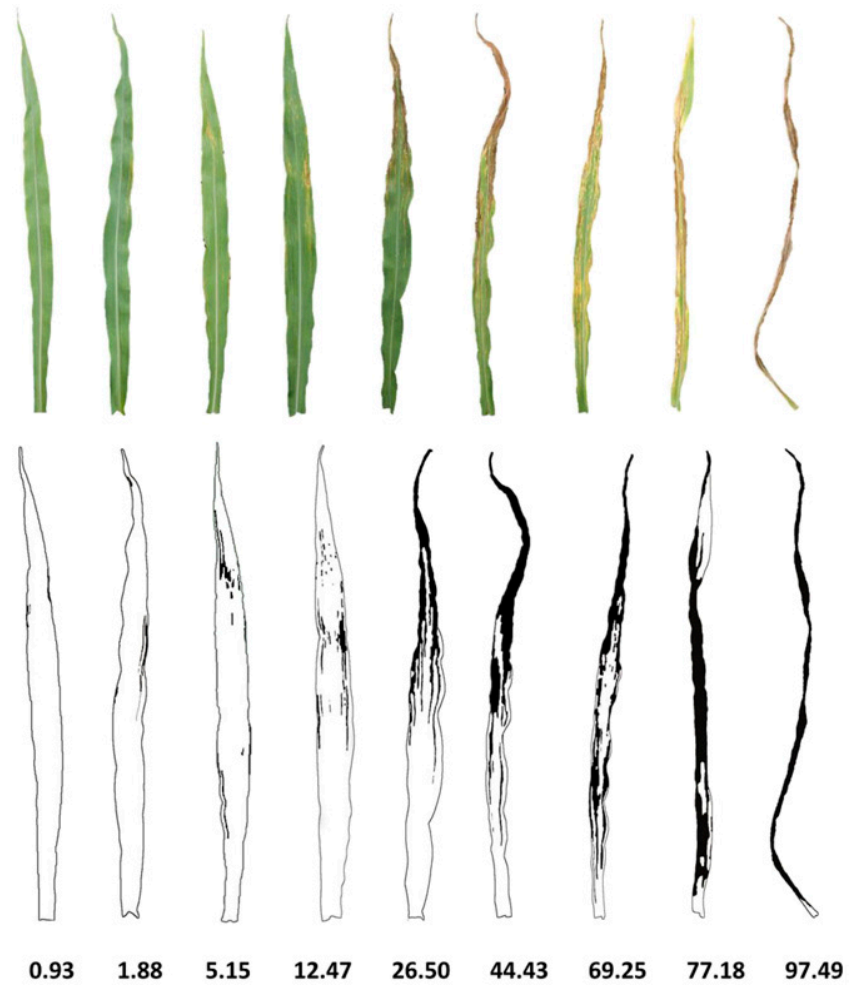

Fig. 1. Diagrammatic scale for assessment of bacterial leaf streak (Xanthomonas vasicola pv. vasculorum) on young plants of maize. The numbers below each leaf represent the actual percentage of the leaf area affected by the disease.

Table 3. Accuracy, precision, and reproducibility of bacterial leaf streak (Xanthomonas vasicola pv. vasculorum) assessments using or without using a diagrammatic scale based on the coefficient of determination $\left(R^{2}\right)$, linear $\left(\beta_{0}\right)$ and angular $\left(\beta_{l}\right)$ coefficients, and the mean square error (MSE) from regression analysis for real versus estimated severity levels, and standard deviation from the parameter estimates ${ }^{z}$

\begin{tabular}{|c|c|c|c|c|c|c|c|c|}
\hline \multirow[b]{2}{*}{ Evaluator } & \multicolumn{4}{|c|}{ Without scale } & \multicolumn{4}{|c|}{ With scale } \\
\hline & $R^{2}$ & $\boldsymbol{\beta}_{0}$ & $\boldsymbol{\beta}_{1}$ & MSE & $R^{2}$ & $\boldsymbol{\beta}_{\boldsymbol{\theta}}$ & $\boldsymbol{\beta}_{1}$ & MSE \\
\hline \multicolumn{9}{|l|}{ Unexperienced } \\
\hline E1 & 0.873 & $-0.26 \mathrm{~ns}$ & $0.90 \mathrm{~ns}$ & 7.58 & 0.998 & $0.22 \mathrm{~ns}$ & $0.99 \mathrm{~ns}$ & 1.04 \\
\hline E2 & 0.895 & $0.88 \mathrm{~ns}$ & $1.06 \mathrm{~ns}$ & 8.01 & 0.995 & $0.11 \mathrm{~ns}$ & $0.99 \mathrm{~ns}$ & 1.59 \\
\hline E3 & 0.897 & $1.72 \mathrm{~ns}$ & $0.93 \mathrm{~ns}$ & 6.99 & 0.995 & $0.13 \mathrm{~ns}$ & $0.98 \mathrm{~ns}$ & 1.61 \\
\hline $\mathrm{E} 4$ & 0.862 & $-2.53 \mathrm{~ns}$ & $1.01 \mathrm{~ns}$ & 8.98 & 0.980 & $-0.39 \mathrm{~ns}$ & $0.99 \mathrm{~ns}$ & 3.15 \\
\hline E5 & 0.930 & $0.73 \mathrm{~ns}$ & $0.94 \mathrm{~ns}$ & 5.72 & 0.998 & $0.01 \mathrm{~ns}$ & $1.00 \mathrm{~ns}$ & 0.86 \\
\hline \multicolumn{9}{|l|}{ Experienced } \\
\hline E6 & 0.907 & $-0.73 \mathrm{~ns}$ & $0.99 \mathrm{~ns}$ & 7.05 & 0.994 & $-0.33 \mathrm{~ns}$ & $1.01 \mathrm{~ns}$ & 1.76 \\
\hline E7 & 0.920 & $2.02 \mathrm{~ns}$ & $1.14 \mathrm{~ns}$ & 7.46 & 0.982 & $0.67 \mathrm{~ns}$ & $0.97 \mathrm{~ns}$ & 2.93 \\
\hline E8 & 0.971 & $1.13 \mathrm{~ns}$ & $0.98 \mathrm{~ns}$ & 3.79 & 0.998 & $0.33 \mathrm{~ns}$ & $0.99 \mathrm{~ns}$ & 0.85 \\
\hline E9 & 0.919 & $4.29 *$ & $1.01 \mathrm{~ns}$ & 6.60 & 0.988 & $-0.18 \mathrm{~ns}$ & $0.99 \mathrm{~ns}$ & 2.46 \\
\hline E10 & 0.920 & $1.92 \mathrm{~ns}$ & $0.92 \mathrm{~ns}$ & 6.55 & 0.990 & $0.61 \mathrm{~ns}$ & $0.98 \mathrm{~ns}$ & 2.14 \\
\hline \multicolumn{9}{|l|}{ Mean } \\
\hline General & 0.909 & 0.92 & 0.99 & 6.87 & 0.992 & 0.11 & 0.99 & 1.84 \\
\hline Unexperienced & 0.891 & & & & 0.993 & & & \\
\hline Experienced & 0.927 & & & & 0.990 & & & \\
\hline Standard deviation & 0.031 & 1.83 & 0.07 & 1.39 & 0.007 & 0.36 & 0.01 & 0.82 \\
\hline
\end{tabular}

${ }^{\mathrm{z}}$ Asterisk (*) and ns indicate conditions in which the null hypotheses $\left(\mathrm{H}_{0}: \beta_{0}=0 ; \mathrm{H}_{0}: \beta_{1}=1\right)$ were rejected $(P \leq 0.05)$ or accepted $(P>0.05)$ by the $t$ test, respectively. 
hydathodes, lenticels, and stomata (Nelson and Dickey 1970). In this context, the syringe injection and spraying without injury inoculation methods may have provided more favorable conditions for $X v v$ infection of leaves of the maize plants, through both wounds and stomata, in the different leaf stages.

BLS symptoms only in leaves of the stages V2 and V3 of the corn plants inoculated with the spraying on injured leaves method may be related to the inoculum being applied only to these leaves. In contrast, the spraying without injury inoculation was a very efficient method to induce BLS symptoms under controlled conditions on leaves of the different vegetative stages of the maize plants. Besides the high disease incidence and severity levels provided by this method of inoculation, the spraying of the uninjured leaf is certainly the closest one to $X v v$ infection that occurs under natural conditions. Under field conditions, the $X v v$ bacterium may survive in infected crop residues and on alternative hosts (Broders 2017). From these sources of inoculum, $X v v$ may be disseminated by blowing wind and rainwater to cause new infections in the maize plants (Arias et al. 2018).

Diagrammatic scales have been widely used as a tool to determine the severity level of several leaf diseases in different field and fruit crops (Godoy et al. 2006; Librelon et al. 2015; Santos and Spósito 2018; Schwanck and Del Ponte 2014). For maize diseases, the diagrammatic scales have also improved visual estimates of Phaeosphaeria leaf spot (Phaeosphaeria maydis) (Sachs et al. 2011), maize leaf blight (Exserohilum turcicum) (Lazaroto et al. 2012), and northern corn leaf blight (Setosphaeria turcica) (Vieira et al. 2014). However, to date no diagrammatic scale had been developed to evaluate the severity of BLS in maize plants, including young plants. The inoculation of maize hybrids of different levels of disease susceptibility allowed obtaining leaves with a wide range of disease severity and developing a scale with severity levels ranging from less than $1 \%$ up to close to $98 \%$ (Fig. 1). In addition, the leaves used for
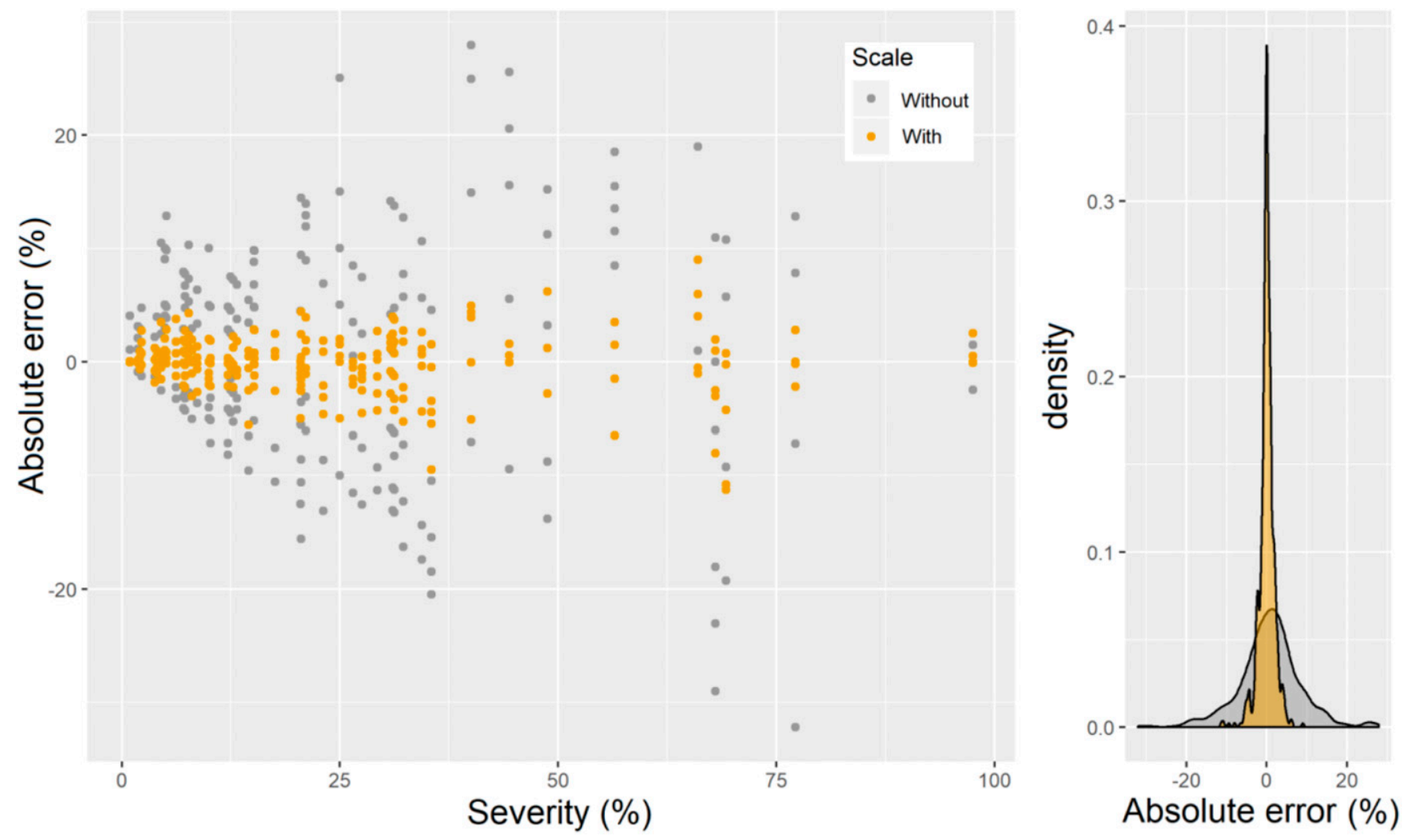

Fig. 2. Absolute error in severity estimates of bacterial leaf streak, caused by Xanthomonas vasicola pv. vasculorum, in young plants of maize.

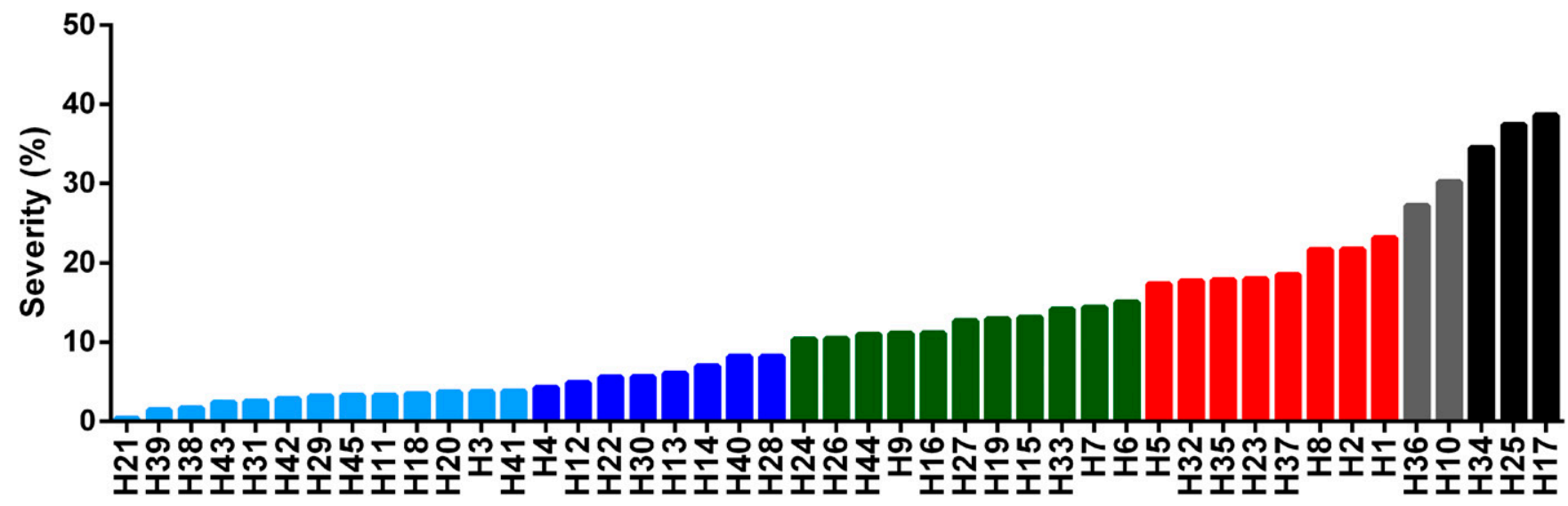

Fig. 3. Evaluation of the reaction to bacterial leaf streak, Xanthomonas vasicola pv. vasculorum, of 45 commercial maize hybrids under greenhouse conditions based on disease severity on the V3, V4, and V5 leaf stages using the proposed diagrammatic scale. Different colored bars are related to the groups formed based on cluster analysis (Scott and Knott 1974). 
the development of the BLS diagrammatic scale were obtained under controlled conditions and certainly were free of other maize diseases that could interfere with the evaluation of the bacterial disease. Furthermore, the reproducibility of the disease evaluations among experienced and even unexperienced evaluators is an important criterion for the analysis of the efficiency of diagrammatic scales (Del Ponte et al. 2017). The reproducibility can be determined based on the standard deviation of each parameter. In the present study, lower standard deviations were observed when the diagrammatic scale was used to evaluate BLS severity. Therefore, the proposed diagrammatic scale contributed to increase the accuracy and precision in BLS severity evaluations in young maize plants.

The high BLS severity levels obtained in the development of this diagrammatic scale are probably related to the favorable environmental conditions provided to produce the set of diseased leaves used to construct the scale, as well as the high susceptibility to the disease of some maize hybrids included in the study. According to Sivits et al. (2018), BLS is positively correlated with air moisture levels due to stomata openings, allowing the tissue invasion and colonization by the pathogen. So far, the economic damage caused by this maize disease has not been determined. However, in some U.S. regions where the disease reached epidemic proportions, the incidence and severity levels were above 90 and 50\%, respectively in $X v v$ susceptible hybrids, indicating the high aggressiveness of this bacterial pathogen (Broders 2017).

Early screening for disease resistance under controlled conditions has been considered as an important strategy in crop breeding programs (Soliman et al. 2018). This procedure can optimize breeding programs by allowing early identification of resistant and/or susceptible genotypes. In addition, genotypes can be evaluated in a short period at any time of the year, because the appropriate environmental conditions can be provided for disease development. Further, the presence of other diseases that could interfere with the identification and quantification of the target disease can be avoided.

The efficiency of resistance discrimination is related to a range of disease levels that allows differentiating genotypes based on statistical analyses in an appropriate design. In this study, a wide range of BLS levels was observed in the leaves of the V3, V4, and V5 stages of young maize plants, allowing a reliable differentiation of resistant and susceptible genotypes. Thirteen maize hybrids were considered BLS resistant, which are promising to be included in breeding programs as sources of resistance for this bacterial disease.

Some hybrids included in the present study were also evaluated under field conditions, with natural occurrence of BLS (data not shown). A high correlation between field and greenhouse data was observed for these hybrids, indicating that early evaluation for reaction to BLS can be a reliable procedure for genotype selection for $X v v$ resistance. To date, no studies of genetic $X v v$ resistance control in maize are available. Therefore, the results obtained in this study are important contributions to better understand the disease, in particular for maize breeding programs aimed at BLS control by genetic resistance.

\section{Literature Cited}

Arias, S., Block, C. C., Mayfield, D. A., Broders, K. D., Jackson-Zierns, T. A., and Munkvold, G. P. 2018. Potential for seed transmission of Xanthomonas vasicola pv. vasculorum on maize collected from fields in the United States. (Abstract). Proceedings of the International Congress of Plant Pathology, Boston, MA.

Arnhold, E. 2013. Package in the R environment for analysis of variance and complementary analyses. Braz. J. Vet. Res. Anim. Sci. 50:488-492.

Bock, C. H., Hotchkiss, M. W., and Wood, B. W. 2015. Assessing disease severity: Accuracy and reliability of rater estimates in relation to number of diagrams in a standard area diagram set. Plant Pathol. 65:261-272.

Broders, K. 2017. Status of bacterial leaf streak of corn in the United States. Proceedings of the Integrated Crop Management Conference. Iowa State University, Digital Press. https://lib.dr.iastate.edu/icm/2017/proceedings/ $18 /$.

Brunner, E., Dette, H., and Munk, A. 1997. Box-type approximations in nonparametric factorial designs. J. Am. Stat. Assoc. 92:1494-1502.

Brunner, E., and Puri, M. L. 2001. Nonparametric methods in factorial designs. Stat. Pap. (Berl.) 42:1-52.

Campbell, C. L., and Madden, L. V. 1990. Introduction to Plant Disease Epidemiology. Wiley, New York, NY.
Coutingo, T. A., and Wallis, F. M. 1991. Bacterial streak disease of maize (Zea mays L.) in South Africa. J. Phytopathol. 133:112-120.

Del Ponte, E. M., Pethybridge, S. J., Bock, C. H., Michereff, S. J., Machado, F. J., and Spolti, P. 2017. Standard area diagrams for aiding severity estimation: Scientometrics, pathosystems, and methodological trends in the last 25 years. Phytopathology 107:1161-1174.

Godoy, C. V., Koga, L. J., and Canteri, M. G. 2006. Diagrammatic scale for assessment of soybean rust severity. Fitopatol. Bras. 31:63-68.

Jacques, M. A., Arlat, M., Boulanger, A., Boureau, T., Carrère, S., Cesbron, S., Chen, N. W. G., Cociancich, S., Darrasse, A., Denance, N., Fischer-Le Saux, M., Gagnevin, L., Koebnik, R., Lauber, E., Noel, L. D., Pieretti, I., Portier, P., Olivier, O., Rieux, A., Robene, I., Royer, M., Szurek, B., Verdier, V., and Verniere, C. 2016. Using ecology, physiology, and genomics to understand host specificity in Xanthomonas. Annu. Rev. Phytopathol. 54:163-187.

Jorge, V., and Verdier, V. 2002. Qualitative and quantitative evaluation of cassava bacterial blight resistance in $\mathrm{F} 1$ progeny of a cross between elite cassava clones. Euphytica 123:41-48.

Karamura, G., Smith, J., Studholme, D., Kubiriba, J., and Karamura, E. 2015 Comparative pathogenicity studies of the Xanthomonas vasicola species on maize, sugarcane and banana. Afr. J. Plant Sci. 9:385-400.

Kauffman, H. E., Reddy, A. P. K., Hsieh, S. P. Y., and Merca, S. D. 1973. An improved technique for evaluating resistance of rice varieties to Xanthomonas oryzae (bacterial blight). Plant Dis. Rep. 57:537-541.

Kim, J., Taylor, K., Hotson, A., Keegan, M., Schmelz, E. A., and Mudgett, M. 2008. XopD SUMO protease affects host transcription, promotes pathogen growth, and delays symptom development in Xanthomonas-infected tomato leaves. Plant Cell 20:1915-1929.

Korus, K. A., Lang, J. M., Adesemoye, A. O., Block, C. C., Pal, N., Leach, J. E., and Jackson-Ziems, T. A. 2017. First report of Xanthomonas vasicola causing bacterial leaf streak on corn in the United States. Plant Dis. 101:1030.

Kranz, J. 1988. Measuring plant disease. Pages 35-50 in: Experimental Techniques in Plant Disease Epidemiology. J. Kranz and J. Rotem, eds. Springer Verlag, New York, NY.

Lang, J. M., DuCharme, E., Ibarra Caballero, J., Luna, E., Hartman, T., OrtizCastro, M., Korus, K., Rascoe, J., Jackson-Ziems, T. A., Broders, K., and Leach, J. E. 2017. Detection and characterization of Xanthomonas vasicola pv. vasculorum (Cobb 1894) comb. nov. causing bacterial leaf streak of corn in the United States. Phytopathology 107:1312-1321.

Lazaroto, A., dos Santos, I., Malagi, A. K. G., and Camochena, V. R. C. 2012. Escala diagramática para avaliação de severidade da helmintosporiose comum em milho. Cienc. Rural 42:2131-2137.

Leite, R. P., Jr., Custódio, A. P., Madalosso, T., Robaina, R. R., Duin, I. M., and Sugahara, V. H. 2018a. First report of the occurrence of bacterial leaf streak of corn caused by Xanthomonas vasicola pv. vasculorum in Brazil. Plant Dis. 103:145.

Leite, R. P., Jr., Custódio, A. P., Madalosso, T., Robaina, R. R., Duin, I. M., and Sugahara, V. H. 2018b. Estria bacteriana do milho no Paraná. Informe da Pesquisa, no. 160. IAPAR, Londrina, PR, Brazil.

Librelon, S. S., Souza, E. A., Pereira, R., Pozza, E. A., and Abreu, A. F. B. 2015 Diagrammatic scale to evaluate angular leaf spot severity in primary leaves of common bean. Australas. Plant Pathol. 44:385-395.

Lozano, J., and Laberry, R. 1982. Screening for resistance to cassava bacterial blight. Plant Dis. 66:316-318.

Malagi, G., dos Santos, I., Camochena, R. C., and Moccellin, R. 2011. Elaboração e validação da escala diagramática para avaliação da mancha branca do milho. Rev. Cienc. Agron. 42:797-804.

Mendiburu, F. D., and Simon, R. 2015. Agricolae - Ten years of an open source statistical tool for experiments in breeding, agriculture and biology. PeerJ PrePrints 3:e1404 v1.

Nelson, P. E., and Dickey, R. S. 1970. Histopathology of plants infected with vascular bacterial pathogens. Annu. Rev. Phytopathol. 8:259-280.

Noguchi, K., Gel, Y. R., Brunner, E., and Konietschke, F. 2012. nparLD: An R software package for the nonparametric analysis of longitudinal data in factorial experiments. J. Stat. Softw. 50:1-23.

Nutter, F. W., Jr., and Schultz, P. M. 1995. Improving the accuracy and precision of disease assessments: Selection of methods and use of computer-aided training programs. Can. J. Plant Pathol. 17:174-184.

Plazas, M. C., De Rossi, R. L., Brucher, E., Guerra, F. A., Vilaró, M., Guerra, G. D., Wu, G., Ortiz-Castro, M. C., and Broders, K. 2018. First report of Xanthomonas vasicola pv. vasculorum causing bacteria leaf streak of maize (Zea mays) in Argentina. Plant Dis. 102:1026.

Rawlings, J. O., Pantula, S. G., and Dickey, D. A. 1998. Applied Regression Analysis: A Research Tool, 2nd Ed. Springer-Verlag, New York, NY.

Restrepo, S., Duque, M., and Verdier, V. 2000. Characterization of pathotypes among isolates of Xanthomonas axonopodis pv. manihotis in Colombia. Plant Pathol. 49:680-687.

Sachs, P. J. D., Neves, C. S. V. J., Canteri, M. G., and Sachs, L. G. 2011. Escala diagramática para avaliação da severidade da mancha branca em milho. Summa Phytopathol. 37:202-204.

Santos, R. F., and Spósito, M. B. 2018. Improving assessments of anthracnose severity on grapevine leaves through the development of a standard area diagram set. Australas. Plant Pathol. 47:357-364.

Schwanck, A. A., and Del Ponte, E. M. 2014. Accuracy and reliability of severity estimates using linear or logarithmic disease diagram sets in true colour or black and white: A study case for rice brown spot. J. Phytopathol. 162:670-682. 
Scott, A. J., and Knott, M. 1974. A cluster analysis method for grouping means in the analysis of variance. Biometrics 30:507-512.

Sivits, S. A., Hartman, T. M., and Jackson-Ziems, T. A. 2018. Bacterial Leaf Streak Disease of Corn. http://extensionpublications.unl.edu/assets/pdf/ec3034.pdf.

Socquet-Juglard, D., Patocchi, A. J. F., Pothier, J. F., Christen, D., and Duffy, B. 2012 Evaluation of Xanthomonas arboricola pv. pruni inoculation techniques to screen for bacterial spot resistance in peach and apricot. J. Plant Pathol. 94:S1.91-S1.96.
Soliman, A., Gulden, R. H., Tambong, J. T., Bajracharya, P., Adam, L. R., Xu, R., Cott, M., and Daayf, F. 2018. Developed and validated inoculation and disease assessment methods for Goss's bacterial wilt and leaf blight disease of corn Crop Prot. 112:159-167.

Vieira, R. A., Mesquini, R. M., Silva, C. N., Hata, F. T., Tessmann, D. J., and Scapim, C. A. 2014. A new diagrammatic scale for the assessment of northern corn leaf blight. Crop Prot. 56:55-57. 